\title{
Determinants of Political Participation in Côte d'Ivoire: The Case of Voting
}

\author{
Zié Ballo \\ University of Cocody-Abidjan and Economic Policy Analysis Unit of CIRES (CAPEC), Abidjan, Côte d'Ivoire
}

\begin{abstract}
This paper assesses electoral participation and studies the determinants of such participation, focusing on presidential elections in Côte d'Ivoire. We use a dataset on elections in Africa and a survey financed by the European Commission and conducted by the Ivorian Center of Social and Economic Research (CIRES) in 2005. We find a decline in voter turnout since 1990 for both presidential and parliamentary elections. We also find that the probability of voting varies across ethnic groups and significantly increases with education levels, interest in politics, satisfaction with democracy and satisfaction with government but decreases with insecurity during elections. Moreover, we show that there is an inverted U-shaped relationship between age and the probability of voting. This probability is higher for men than women and for workers and retirees compared to unemployed, but it is low for students. Concerning the vote choice, we find that relative to the "program and party" criterion, the probability of choosing the candidate on the basis of his individual characteristics decreases with age, insecurity, satisfaction with democracy while it increases with satisfaction with government and with secondary, university or Koran education level.
\end{abstract}

Keywords: participation, voting, Côte d'Ivoire

\section{Introduction}

Political participation describes any voluntary act to influence elections or public policy. It includes voting, protesting, lobbying, trying to persuade others to vote and many other activities. Voting is a crucial process in democracies. Following the wave of democratization during the 1990s, elections have become common in low-income countries. They are viewed as a pacific and democratic means to conflict and political crisis resolution in Africa. Indeed, events in Africa have witnessed electoral systems designed to sustain an ethnic conflict resolution process. Sudan, where conflict continues between the Muslimnorth and non-Muslimsouth, endeavor to establish a democratic constitution, after the overthrow of Numeri in 1985, and led to democratic elections in 1986. In Angola, the 1991 Bicesse and the 1994 Lusaka peace agreements included an agreement to hold elections in 1992 and in 1998, respectively. Similarly, holding elections was among the main objectives of the political transition initiated in Democratic Republic of Congo (RDC), Liberia, Sierra Leone, Burundi and Côte d'Ivoire following peace agreements (Mangu, 2008). However, in many countries such as Togo, RDC, Nigeria, Kenya, Zimbabwe and Côte d'Ivoire, the electoral competition has produced serious levels of violence. Such a relationship between elections and violence has been confirmed by theoretical and empirical studies. Rocco and

Zié Ballo, Ph.D., Professor of Economics, Department of Economics, University of Cocody-Abidjan and Economic Policy Analysis Unit of CIRES (CAPEC).

Correspondence concerning this article should be addressed to Zié Ballo, CAPEC-CIRES, 08 BP 1295 Abidjan 08, Côte d’Ivoire. E-mail: zieballo@hotmail.com. 
Ballo (2008) show that a civil war is more likely when the government suffers from high risk of being overthrown, either through regular elections or a coup attempt. Collier and Rohner (2008) find that, below a per capita income of $\$ 2,750$, democracy significantly increases proneness to civil war and various other manifestations of violence. Collier and Vicente (2008) explain this effect of democracy by focusing on how elections have been conducted. Specifically, they point out that numerous recent African elections aroused widespread international accusations that parties/candidates had resorted to miscounting of votes, bribery, and/or intimidation. Then, they investigate the causes and consequences of such illegitimate strategies using a field experiment on the Nigerian general election of 2007. They establish that voter intimidation is effective in reducing voter turnout and that violence was systematically associated with non-incumbent groups. They also suggest that incumbents have a comparative advantage in alternative strategies, such as vote buying and ballot fraud. They explain the use of violence by a weak candidate by the fact that it strengthens his post-election position.

Together, the results obtained by Collier and Vicente (2008) suggest that to lower parties/candidates incentives to resort to illegitimate strategies, it is important to help them increasing their voting share. This can be achieved through the knowledge of the correlates of the decision to participate in elections and of the candidate choice.

This paper studies the correlates of electoral participation in Côte d'Ivoire. In this country, following the exclusion of candidates from the 2000 presidential elections, a civil war burst out in September 2002. To end this war, it has been decided to organize transparent elections with no exclusion of candidates. The presidential elections were finally held on October 31, 2010 and 14 candidates, including a woman, registered and campaigned. The provisional results were released by the electoral commission (CEI) on November 2, 2010, and these results were later confirmed by the Constitutional Court and the United Nations Operation in Côte d'Ivoire ${ }^{1}$. Laurent Gbagbo was the frontrunner with 38.06\%. He was directly followed by Alassane Ouattara (32.26\%), Konan Bedié (25.01\%) and Mabri Toikeusse (2.59\%) ${ }^{2}$. Since no candidate won an outright majority, a second round of voting took place on November 28, 2010 between the two frontrunners. The principal opposition alliance RHDP which includes 4 political parties ruling by Ouattara, Bedié, Toikeusse and Anaky Kobenan decided to rally behind Alassane Ouattara, while most of the 10 remaining candidates called to vote for Laurent Gbagbo. On December 2, 2010, the CEI proclaimed Alassane Ouattara the winner of the election with 54.1\% of the votes against Laurent Gbagbo who obtained $45.9 \%$ of the votes cast, while a few hours later, the Constitutional Council cancelled votes in seven regions in the north citing electoral fraud and handed victory to Gbagbo. The international observers said while there were some cases of irregularities across the country, the election was broadly free and fair and that Ouattara won ${ }^{3}$. From its part, the United Nations Operation endorsed the victory of Ouattara. The international community also recognized Ouattara as the winner and put pressure on Gbagbo to accept the verdict of the electoral commission and step down as president. The latter refused to relinquish power, leading to another crisis.

As noted above, by providing evidence on the determinants of both the decision to vote and the vote choice, this paper aims to reduce parties/candidates incentives to rely upon illegitimate strategies for getting elected.

Various determinants have been underlined by research on political participation. Following Verba and Nie (1972), studies on the determinants of the different forms of political participation (voting, campaign activity, communal activity, demonstrations...) distinguish two classes of determinants: socio-demographic

\footnotetext{
${ }^{1}$ The United Nations mission is mandated to certify the conduct and outcome of the election by the terms of the peace accord that set in motion the electoral process.

${ }^{2}$ Each of the 10 remaining candidates won less than $0.40 \%$.

${ }^{3}$ Especially, observers of the European Union and African Union.
} 
characteristics and attitudes. Socio-demographic characteristics include variables such as education, age, income and sex. These variables have been found to consistently explain the variation in such forms of political participation as voting or joining voluntary associations (Milbrath \& Goel, 1977). However, the strongest predictors of political participation are age and education (Winkler, Judd, \& Kelman, 1981; Grönlund \& Setälä, 2007). Attitudes are psychological characteristics that could affect political participation. They are captured by qualitative variables such as political trust or alienation (Winkler et al., 1981; Hetherington, 1999), trust in parliament, trust in politicians and satisfaction with democracy (Grönlund \& Setälä, 2007), abilities (Brady, Verba, \& Schlozman, 1995), sense of civic duty (Dalton, 2007), party identification (Dalton \& Wattenberg, 2001), political interest (Fournier et al., 2007) and so on.

Studies on vote choice use the explanatory variables of political participation and additional variables such as race, candidate characteristics, retrospective evaluations of incumbent performance, national economic conditions as determinants (Hetherington, 1999). These studies analyze the vote choice using a Logit model (Hetherington, 1999) or a multinomial Logit model while studies on the decision to vote estimate the propensity to vote using a Logit model (Grönlund \& Setälä, 2007).

In this paper, we use some of the determinants mentioned above and specific variables to analyze the decision to vote and the vote choice in Côte d'Ivoire. Similar to previous studies, the probability to participate in elections, as well as the vote choice, is estimated using a Logit model. The next section provides some information on data and variables. Section 3 presents the results and section 4 concludes.

\section{Data on Electoral Participation in Côte d'Ivoire}

We use the database on African elections from the Macro Data Guide of the Norwegian Social Science Data Services (NSD) (Retrieved from http://africanelections.tripod.com/ci.html) and statistics on parliamentary elections collected from the website of the National Assembly of Côte d'Ivoire (Retrieved from http://www.anci.ci/Deputes/statistiques.asp) to have a global trend in electoral participation in Côte d'Ivoire. The data cover the period from 1990 to 2000. We also use a survey conducted in the district of Abidjan in 2005 to establish the determinants of electoral participation and therefore, draw some policy implications.

\section{Trends of Electoral Participation}

Following the re-establishment of the multiparty system in Côte d'Ivoire in April 1990, several political parties were created. However, only a few of them participated in the presidential elections. Indeed, presidential election was a contest between two political parties-Democratic Party of Côte d'Ivoire (PDCI) and Ivorian Popular Front (FPI) — out of fourteen parties in 1990, two parties out of around 29 (PDCI and Ivorian Workers Party (PIT), in 1995 and three parties and two independent candidates out of 80 parties in 2000 (see Table 1). Several explanations have been provided to justify this low participation. For example, two weeks before the 1990 presidential elections, a law establishing the payment of a 20 million CFA bail bond by each candidate was promulgated. This law and the short deadline to pay off the bail bond prevented parties from participating in elections. In 1995, the two major opposition parties, Rally of the Republicans (RDR) and FPI, boycotted the presidential elections because of the new electoral system adopted in $1994^{4}$ and of the fact that the ruling party (PDCI) did not fulfill their claims for clean elections $^{5}$. Finally, in the 2000 presidential elections the Constitutional Council in charge of appointing candidates

\footnotetext{
${ }^{4}$ According to this law a candidate for presidential election must be an Ivorian citizen whose parents are Ivorian Natives.

5 These claims were: an independent electoral commission, equal access to the public media and the financing of parties by the government.
} 
rejected fourteen applications out of nineteen based on the new Constitution, adopted by referendum in 2000 . Among the excluded candidates were the candidates of the two formerly largest political parties (PDCI \& RDR). Therefore, such exclusions were interpreted as a strategy of the ruling Junta to increase its chance of winning elections (Rocco \& Ballo, 2008). Despite of the ruling junta's maneuvers, the candidate of the Ivorian Popular Front won elections. Concerning parliamentary elections, we note an increased participation of political parties. However, few of them are represented in the parliament (see Table 2). Over the past ten years, the average voter turnout declined both for presidential elections (-26.48\%) and parliamentary elections (-11.26\%). The turnout during presidential elections steadily decreased from $69.2 \%$ in 1990 to $56 \%$ in 1995 and from 56\% to $37.4 \%$ in 2000, while for parliamentary elections, the turnout increased from 40\% in 1990 to $45 \%$ in 1995 and then decreased from 45\% to 31.5\% (see Table 3). While the relatively high turnout recorded of $69.2 \%$ in 1990 may be explained by the fact that some of the non-Ivoirians from African countries living in Côte d'Ivoire also voted ${ }^{6}$, the turnout of 56\% in 1995 may be explained by the boycott of the elections by the FPI and RDR, the suppression of the rights to vote for African nationals resident in Côte d'Ivoire following the adoption of the new electoral law in 1995 (Bouquet, 2002). This law was also used to question the nationality of Northerners (Bouquet, 2007; Rocco \& Ballo, 2008). On the other hand, the turnout of $31.5 \%$ could be explained by the boycott of the elections by the Rally of Republicans (RDR) and Democratic Party of Côte d'Ivoire (PDCI).

Table 1

Presidential Elections Results in 1990-2000

\begin{tabular}{llcc}
\hline Parties & 1990 & 1995 & 2000 \\
\hline PDCI-RDA & $81.68 \%$ & $96.44 \%$ & \\
FPI & $18.32 \%$ & $3.52 \%$ & $59.4 \%$ \\
PIT & & & $5.7 \%$ \\
RDR & & \\
UDCI & & $1.5 \%$ \\
UDPCI & & $32.7 \%$ \\
MFA & & $0.8 \%$ \\
Independents & & \\
\hline
\end{tabular}

Note. Source: Retrieved from http://africanelections.tripod.com/ci.html.

Table 2

Parliamentary Elections (Number of Seats)

\begin{tabular}{lccc}
\hline Parties & 1990 & 1995 & 2000 \\
\hline PDCI-RDA & 163 & 148 & 98 \\
FPI & 9 & 14 & 96 \\
PIT & 1 & & 4 \\
RDR & & 14 & 1 \\
UDCI & & & 13 \\
UDPCI & & & 1 \\
MFA & & & 10 \\
Mouvement national citoyen & 2 & 29 & 80 \\
Independents & 19 & & \\
Number of parties that participate in elections & 19 &
\end{tabular}

Note. Source: Retrieved from http://africanelections.tripod.com/ci.html and http://www.anci.ci/Deputes/statistiques.asp.

${ }^{6}$ The right to vote was granted to non-Ivoirians from African country living in Cote d'Ivoire by the President, exceptionally for 1990 elections (see Journal Officiel de la republique de Côte d'Ivoire du October 18, 1990). 
Table 3

Voter Turnout Over the Period of 1990-2000

\begin{tabular}{lllll}
\hline & 1990 & 1995 & 2000 & Average rate of change \\
\hline Presidential elections & $69.2 \%$ & $56 \%$ & $37.4 \%$ & $-26.48 \%$ \\
Parliamentary elections & $40 \%$ & $45 \%$ & $31.5 \%$ & $-11.26 \%$ \\
Referendum & & & $56 \%$ & \\
\hline
\end{tabular}

Note. Source: Retrieved from http://africanelections.tripod.com/ci.html.

The voters' participation in the parliamentary elections has weakened by $21 \%$ during $1990-2000$. This rate is lower than of presidential elections in the same period. To increase the participation at the future elections and facilitate victory we are presently examining the determinants of voting decision and the choice of the elected candidate.

\section{Statistics of the Determinants of Electoral Participation}

As already mentioned, to study the determinants of electoral participation we use the survey conducted in the district of Abidjan in 2005. This survey was financed by the European Commission and carried out by the Ivorian Center of Social and Economic Research (CIRES). A total of 6,545 individuals were interviewed. Five thousand four hundred and ninety-six of these individuals were Ivoirians and 1,049 non-Ivoirians. Three thousand eight hundred and ninety-six of the 5,496 Ivoirians were at least 18 years old (i.e., the voting age) in 2000 (i.e., the year of the 2000 presidential elections).

The questionnaire includes questions on socio-demographic characteristics of the households' members, expenses of the households, democracy and human rights, impact of the civil war, and on the opinion about the end of the war. With respect to electoral participation, there were questions about whether respondents had voted in presidential, municipal, parliamentary or regional elections during the last five years. Sixty eight point two two percent of the 3,896 Ivoirians said that they voted during at least one election during the last five years. Sixty three point eight nine percent voted in presidential elections, $58.01 \%$ in parliamentary elections, $60.09 \%$ in municipal elections and $48.09 \%$ in regional elections. These turnouts are over reported as national voter turnouts in presidential, parliamentary, municipal and regional elections in 2000 are 37.4\%, 31.5\%, 40\% and 28.01\% ${ }^{7}$. There were also questions on the reasons why certain respondents did not vote. Among the 1,238 respondents who did not vote, 173 reported that they did not have the Ivorian identity card, 146 answered that were not on the electoral roll, 62 said that they feared insecurity and 857 reported other reasons (disinterest, rejection of the application of the favorite, trip, illness...).

Finally, there were questions on the main motives for the choice of a candidate in each poll. For example, people were asked whether they had chosen a candidate in presidential elections according to the government program, ethnic group, religion, party, or other criteria (experience in politics, wealth, honesty, nationalism, good behavior, peace lover, being a civilian, intelligent...). The proportions of the sample are $13.50 \%$ for government program, $2.31 \%$ for ethnic group, $0.41 \%$ for religion, $6.34 \%$ for party and $77.44 \%$ for other criteria (see Table 6 ).

Let's now examine the correlates of the decision to vote and of the vote choice in presidential elections. Like in the literature, we use almost the same determinants for both the decision to vote and the vote choice. They include socio-demographics characteristics and attitudes. The socio-demographics characteristics are captured by the following variables: age, sex, education, profession and ethnic group. Age is measured in years (the minimum

\footnotetext{
${ }^{7}$ Voter turnouts in municipal and regional elections are drawn from Bouquet (2002).
} 
age is 23 because the survey takes place 5 years after the presidential elections and the maximum age 99) while sex is a dummy variable which takes the value 1 for men and 0 for women. Education is represented by four dummies variables related to the different levels of education: primary, secondary, university or high school and Koran. Profession includes four dummies variables indicating the occupational status: unemployed, worker, student and retiree. Ethnic group consists of five dummies variables referring to the five main ethnic groups which compose the country: Akan, Krou, Southern Mandé (mands), Northern Mandé (mandn) and Gurr.

For attitudes we use opinions on five variables: democracy, state, politics, insecurity during elections and adhesion to political party. The first variable, democracy, takes the value 1 for respondents who reported that democracy is adapted to Côte d'Ivoire and 0 otherwise. The second, state, is a dummy variable which equals 1 for respondents who answered that the state of Côte d'Ivoire protects the population without discrimination. The third variable, politics, is also a dummy variable coded " 1 " for those who report that they are interested in politics and 0 otherwise. The fourth variable, insecurity, takes the value $1 \mathrm{for}$ respondents who reported that they did not vote because of insecurity or that they were the subject of intimidation during elections and 0 otherwise. The last attitudinal determinant, adhesion, is a set of seven dummies variables related to criteria of the adhesion to political parties: ethnic, religion, money, leader's charisma, government program, other criteria and no criterion.

Table 5 presents some descriptive statistics of the determinants of the propensity to vote. Column one in this table describes the full sample average values of the different variables while columns two and three give the averages for voters and non-voters respectively. The average age is around 36 for the entire sample. Men represent $49.25 \%$ of this sample. The proportions of people having primary, secondary, university (or high school) or Koran education levels are 17.91\%, 33.72\%, 29.85\% and 5.08\% respectively. Workers, students, retirees and unemployed represent $49.07 \%, 14.50 \%, 4.57 \%$ and $31.85 \%$. The proportions of the different ethnic groups in the entire sample are 48.64\% for the Akan, 18.09\% for Krou, 6.95\% for southern Mandé, 21.28\% for northern Mandé and $2.10 \%$ for Gurr. Fifty-two point three one percent of the 3,896 individuals report that democracy is adapted to Côte d'Ivoire and 54.90\% answer that the government protects the population without discrimination. Thirty-one point eight three percent of the 3,896 individuals are interested in politics. Three point nine two percent complain about insecurity during elections. As to the criteria on joining a political party, the proportions of individuals in the full sample who responded that the adhesion is based on the ethnic group, the religion, money, the leader's charisma, the government program, no criterion or other criteria are, $19.94 \%, 3 \%, 10.93 \%$, $5.57 \%, 35.86 \%, 18.32 \%$ and $6.36 \%$ respectively.

Table 4

Descriptive Statistics

\begin{tabular}{lcccc}
\hline Variables & $\begin{array}{l}\text { All individuals } \\
(3,896)\end{array}$ & $\begin{array}{l}\text { Vote } \\
(2,658)\end{array}$ & $\begin{array}{l}\text { Not vote } \\
(1,238)\end{array}$ & $\begin{array}{l}\text { Difference between } \\
\text { not vote and vote }\end{array}$ \\
\hline Age & 36.33 & 38.3546 & 31.506 & -6.848 \\
& $(11.77)$ & $(11.7366)$ & $(10.3652)$ & $(0.39043)^{* * *}$ \\
Sex & 0.4925 & 0.5176 & 0.4386 & -0.0790 \\
& $(0.50)$ & $(0.4998)$ & $(0.4964)$ & $(0.0171)^{* * *}$ \\
Uneducated & 0.1342 & 0.1279 & 0.1478 & 0.0199 \\
& $(0.3409)$ & $(0.3340)$ & $(0.355)$ & $(0.01199)^{*}$ \\
Primary & 0.1791 & 0.1719 & 0.1946 & 0.0227 \\
& $(0.3835)$ & $(0.3774)$ & $(0.3961)$ & $(0.0134)^{*}$ \\
Secondary & 0.3372 & 0.3356 & 0.3408 & 0.0053 \\
& $(0.4728)$ & $(0.4723)$ & $(0.4741)$ & $(0.0163)$ \\
\hline
\end{tabular}


(Table 4 continued).

\begin{tabular}{|c|c|c|c|c|}
\hline Variables & $\begin{array}{l}\text { All individuals } \\
(3,896)\end{array}$ & $\begin{array}{l}\text { Vote } \\
(2,658)\end{array}$ & $\begin{array}{l}\text { Not vote } \\
(1,238)\end{array}$ & $\begin{array}{l}\text { Difference between } \\
\text { not vote and vote }\end{array}$ \\
\hline \multirow[t]{2}{*}{ University } & 0.2985 & 0.3213 & 0.2496 & -0.0717 \\
\hline & $(0.4576)$ & $(0.4670)$ & $(0.4329)$ & $(0.0152)^{* * *}$ \\
\hline \multirow[t]{2}{*}{ Koran } & 0.0508 & 0.0432 & 0.0670 & 0.0238 \\
\hline & $(0.2196)$ & $(0.2035)$ & $(0.2502)$ & $(0.0081)^{* * *}$ \\
\hline \multirow[t]{2}{*}{ Worker } & 0.4907 & 0.5496 & 0.3643 & -0.1853 \\
\hline & (0.4999) & $(0.4976)$ & $(0.4814)$ & $(0.0167)^{* * *}$ \\
\hline \multirow[t]{2}{*}{ Student } & 0.1450 & 0.0922 & 0.2585 & 0.1663 \\
\hline & $(0.3521)$ & $(0.2893)$ & $(0.4379)$ & $(0.0136)^{* * *}$ \\
\hline \multirow[t]{2}{*}{ Retiree } & 0.0457 & 0.0602 & 0.0145 & -0.0456 \\
\hline & $(0.2088)$ & $(0.2379)$ & $(0.1197)$ & $(0.0057)^{* * *}$ \\
\hline \multirow{2}{*}{ Unemployed } & 0.3185 & 0.2979 & 0.3627 & 0.0647 \\
\hline & $(0.4659)$ & $(0.4574)$ & $(0.4809)$ & $(0.0163)^{* * *}$ \\
\hline \multirow[t]{2}{*}{ Akan } & 0.4864 & 0.4943 & 0.4693 & -0.025 \\
\hline & $(0.4999)$ & $(0.5000)$ & $(0.4992)$ & $(0.0172)$ \\
\hline \multirow[t]{2}{*}{ Krou } & 0.1809 & 0.1945 & 0.1518 & -0.0426 \\
\hline & $(0.3850)$ & (0.3959) & $(0.3590)$ & $(0.0127)^{* * *}$ \\
\hline \multirow[t]{2}{*}{ Mandé sud } & 0.0695 & 0.0733 & 0.0614 & -0.0119 \\
\hline & $(0.2544)$ & $(0.2607)$ & $(0.2401)$ & $(0.0085)$ \\
\hline \multirow[t]{2}{*}{ Mandé nord } & 0.2128 & 0.1945 & 0.2520 & 0.0575 \\
\hline & $(0.4093)$ & (0.3959) & $(0.4343)$ & $(0.0145)^{* * *}$ \\
\hline \multirow[t]{2}{*}{ Gurr } & 0.0210 & 0.0188 & 0.0258 & 0.0070 \\
\hline & $(0.1435)$ & $(0.1359)$ & $(0.1587)$ & $(0.0052)$ \\
\hline \multirow[t]{2}{*}{ Democracy } & 0.5231 & 0.6079 & 0.3409 & -0.2671 \\
\hline & $(0.4995)$ & $(0.4883)$ & $(0.4742)$ & $(0.0165)^{* * *}$ \\
\hline \multirow[t]{2}{*}{ State } & 0.5490 & 0.6207 & 0.3950 & -0.2257 \\
\hline & $(0.4976)$ & $(0.4853)$ & $(0.4890)$ & $(0.0168)^{* * *}$ \\
\hline \multirow[t]{2}{*}{ Politics } & 0.3183 & 0.3461 & 0.2585 & -0.0876 \\
\hline & $(0.4658)$ & $(0.4758)$ & $(0.4379)$ & $(0.0155)^{* * * *}$ \\
\hline \multirow[t]{2}{*}{ Insecurity } & 0.0392 & 0.0308 & 0.0573 & 0.0265 \\
\hline & $(0.1942)$ & $(0.1729)$ & $(0.2182)$ & $(0.0074)^{* * *}$ \\
\hline \multirow[t]{2}{*}{ Ethnic adhesion } & 0.1994 & 0.2321 & 0.1292 & -0.1029 \\
\hline & $(0.3996)$ & $(0.4223)$ & $(0.3356)$ & $(0.0125)^{* * *}$ \\
\hline \multirow[t]{2}{*}{ Religion adhesion } & 0.0300 & 0.0323 & 0.0250 & -0.0073 \\
\hline & $(0.1707)$ & $(0.1769)$ & $(0.1563)$ & $(0.0056)$ \\
\hline \multirow[t]{2}{*}{ Money adhesion } & 0.1093 & 0.1204 & 0.0856 & -0.0347 \\
\hline & $(0.3121)$ & $(0.3255)$ & $(0.2799)$ & $(0.0101)^{* * * *}$ \\
\hline \multirow[t]{2}{*}{ Charisma adhesion } & 0.0557 & 0.0609 & 0.0444 & -0.0165 \\
\hline & $(0.2293)$ & $(0.2393)$ & $(0.2061)$ & $(0.0075)^{* *}$ \\
\hline \multirow[t]{2}{*}{ Other criteria } & 0.0636 & 0.0605 & 0.0703 & 0.0097 \\
\hline & $(0.2441)$ & $(0.2386)$ & $(0.2557)$ & $(0.0086)$ \\
\hline \multirow[t]{2}{*}{ No opinion adhesion } & 0.1832 & 0.0967 & 0.3691 & 0.2724 \\
\hline & $(0.3869)$ & $(0.2956)$ & $(0.4827)$ & $(0.0148)^{* * *}$ \\
\hline \multirow[t]{2}{*}{ Party adhesion } & 0.3586 & 0.3969 & 0.2762 & -0.1206 \\
\hline & $(0.4796)$ & $(0.4893)$ & $(0.4473)$ & $(0.0158)^{* * *}$ \\
\hline
\end{tabular}

Notes. Numbers in each cell are mean and standard deviation (in brackets). ${ }^{*}$ significant at $10 \%$; ${ }^{* *}$ significant at $5 \% ;{ }^{* * *}$ significant at $1 \%$.

The last column of Table 4 suggests that the variables age, sex, university, retiree, Krou, democracy, state, 
politics, identity card, ethnic adhesion, money adhesion, charisma adhesion and party adhesion positively and significantly affect the probability of voting. On the contrary, illiteracy, primary and Koran educations, student, unemployed, Mandé du nord, and insecurity are negatively and significantly associated with the propensity to vote. However, these observations are only suggestive, and a proper econometric analysis is required to estimate the impacts of each of these variables.

\section{Econometric Results}

\section{Results for the Decision to Vote}

We use a Logit model to estimate the propensity to vote. The dependent variable is a dummy variable taking the value 1 if an individual has voted in the 2000 presidential elections and 0 otherwise. As noted above, the explanatory variables include age, sex, primary, secondary, university or high school, Koran, worker, student, retired, Akan, Krou, southern Mandé (mands), northern Mandé (mandn), democracy, state, politics, insecurity and six of the seven dummies variables related to criteria of the adhesion to political parties: ethnic, religion, money, leader's charisma, other criteria (other), no criterion. We add the square of age to these variables (age 2) to account for the non-linear effect of age. The results of the estimation are reported in Table 5. Column (1) presents the results when we include only the standard determinants of voting. Note that almost all the coefficients are statistically significant. Age is positively associated with voting, implying that individuals who do not vote are more likely to be young. Similarly, sex positively and significantly affects the propensity to vote, suggesting that men are more likely to vote. More precisely, being a man increases the probability of voting by 2.58\% (see column (1) of Table 5.2). All the parameters associated with education variables except Koran are significant. Indeed, having a primary, secondary or university standard significantly increases the probability of voting while having a Koranic standard has no effect. The elasticity of the probability of voting with respect to primary, secondary and university standards is $0.0129,0.0256$ and 0.0696 respectively. Therefore, education has an increasing effect on the propensity to vote. The coefficient of worker is positive and significant while that of student is negative and significant, implying that compared to the unemployed, workers are more likely to vote but students are less likely to vote. Retired people are not more likely to vote than the unemployed. All the coefficients associated with the attitudinal variables are statistically significant. Democracy, State and politics are positively associated with voting like in Grönlund and Setälä (2007). Therefore people who are interested in politics or satisfied with democracy or state have a greater propensity to cast an election ballot. Interest in politics, satisfaction with democracy and satisfaction with State increases the propensity to vote by $11.84 \%, 7.33 \%$ and $3.33 \%$ respectively (see column (1) of Table 5.2 ).

In Table 5 column (2), we include the square of age to account for the non-linear effect of age. Almost all the significant variables of column (1) are still significant. Age positively and significantly affects the probability of voting but its square has a significant negative effect. Therefore, there is an inverted U-shaped relationship of age on the propensity to vote. As in column (1), the variables of sex, primary, university, worker, student, democracy, state and politics are significant with a decreased level of significance for primary (from $1 \%$ to $10 \%$ level) and worker (from $1 \%$ to $5 \%$ level). However, the secondary education variable turns out to be insignificant while the coefficient of the variable retirees becomes significant at the $5 \%$ level.

Column (3) reports the results when the variable insecurity is included in the model. All the significant variables of column (2) are still significant and the sign of the observed relation is robust to the inclusion of insecurity. Moreover, insecurity is negatively and significantly associated with the probability of voting. 
Table 5

Results for the Decision to Participate in Elections

\begin{tabular}{|c|c|c|c|c|c|}
\hline & (1) & (2) & (3) & (4) & (5) \\
\hline Age & $\begin{array}{l}0.062 \\
(0.006)^{* * *}\end{array}$ & $\begin{array}{l}0.273 \\
(0.022)^{* * *}\end{array}$ & $\begin{array}{l}0.279 \\
(0.022)^{* * *}\end{array}$ & $\begin{array}{l}0.283 \\
(0.022)^{* * *}\end{array}$ & $\begin{array}{l}0.281 \\
(0.023)^{* * *}\end{array}$ \\
\hline Age $^{2}$ & & $\begin{array}{l}-0.003 \\
(0.0002)^{* * *}\end{array}$ & $\begin{array}{l}-0.003 \\
(0.0002)^{* * * *}\end{array}$ & $\begin{array}{l}-0.003 \\
(0.0002)^{* * *}\end{array}$ & $\begin{array}{l}-0.003 \\
(0.000)^{* * *}\end{array}$ \\
\hline Sex & $\begin{array}{c}0.210 \\
(0.087)^{* *}\end{array}$ & $\begin{array}{l}0.236 \\
(0.088)^{* * *}\end{array}$ & $\begin{array}{l}0.246 \\
(0.088)^{* * *}\end{array}$ & $\begin{array}{l}0.257 \\
(0.088)^{* * *}\end{array}$ & $\begin{array}{c}0.284 \\
(0.092)^{* * * *}\end{array}$ \\
\hline Primary & $\begin{array}{c}0.292 \\
(0.146)^{* *}\end{array}$ & $\begin{array}{c}0.275 \\
(0.149)^{*}\end{array}$ & $\begin{array}{c}0.264 \\
(0.149)^{*}\end{array}$ & $\begin{array}{c}0.232 \\
(0.150)\end{array}$ & $\begin{array}{c}0.125 \\
(0.158)\end{array}$ \\
\hline Secondary & $\begin{array}{l}0.307 \\
(0.135)^{* *}\end{array}$ & $\begin{array}{c}0.225 \\
(0.139)\end{array}$ & $\begin{array}{c}0.226 \\
(0.140)\end{array}$ & $\begin{array}{c}0.188 \\
(0.141)\end{array}$ & $\begin{array}{c}0.107 \\
(0.148)\end{array}$ \\
\hline University & $\begin{array}{l}0.919 \\
(0.154)^{* * *}\end{array}$ & $\begin{array}{l}0.836 \\
(0.158)^{* * *}\end{array}$ & $\begin{array}{c}0.832 \\
(0.159)^{* * *}\end{array}$ & $\begin{array}{l}0.805 \\
(0.160)^{* * *}\end{array}$ & $\begin{array}{c}0.743 \\
(0.166)^{* * * *}\end{array}$ \\
\hline Koran & $\begin{array}{l}-0.148 \\
(0.201)\end{array}$ & $\begin{array}{l}-0.211 \\
(0.204)\end{array}$ & $\begin{array}{l}-0.234 \\
(0.204)\end{array}$ & $\begin{array}{l}-0.263 \\
(0.205)\end{array}$ & $\begin{array}{l}-0.356 \\
(0.207)^{*}\end{array}$ \\
\hline Worker & $\begin{array}{l}0.336 \\
(0.093)^{* * *}\end{array}$ & $\begin{array}{c}0.239 \\
(0.094)^{* *}\end{array}$ & $\begin{array}{l}0.246 \\
(0.095)^{* * *}\end{array}$ & $\begin{array}{l}0.267 \\
(0.095)^{* * *}\end{array}$ & $\begin{array}{c}0.182 \\
(0.100)^{*}\end{array}$ \\
\hline Student & $\begin{array}{l}-0.793 \\
(0.141)^{* * *}\end{array}$ & $\begin{array}{l}-0.538 \\
(0.143)^{* * *}\end{array}$ & $\begin{array}{l}-0.549 \\
(0.143)^{* * *}\end{array}$ & $\begin{array}{l}-0.538 \\
(0.144)^{* * *}\end{array}$ & $\begin{array}{l}-0.660 \\
(0.152)^{* * *}\end{array}$ \\
\hline Retiree & $\begin{array}{c}0.223 \\
(0.306)\end{array}$ & $\begin{array}{c}0.647 \\
(0.312)^{* *}\end{array}$ & $\begin{array}{c}0.673 \\
(0.306)^{* *}\end{array}$ & $\begin{array}{l}0.694 \\
(0.311)^{* *}\end{array}$ & $\begin{array}{c}0.559 \\
(0.309)^{*}\end{array}$ \\
\hline Democracy & $\begin{array}{c}0.879 \\
(0.084)^{* * *}\end{array}$ & $\begin{array}{c}0.903 \\
(0.087)^{* * * *}\end{array}$ & $\begin{array}{c}0.879 \\
(0.088)^{* * *}\end{array}$ & $\begin{array}{l}0.869 \\
(0.088)^{* * *}\end{array}$ & $\begin{array}{c}0.754 \\
(0.093)^{* * * *}\end{array}$ \\
\hline State & $\begin{array}{c}0.515 \\
(0.084)^{* * *}\end{array}$ & $\begin{array}{c}0.526 \\
(0.086)^{* * * *}\end{array}$ & $\begin{array}{c}0.521 \\
(0.086)^{* * *}\end{array}$ & $\begin{array}{l}0.494 \\
(0.087)^{* * *}\end{array}$ & $\begin{array}{c}0.336 \\
(0.093)^{* * * *}\end{array}$ \\
\hline Politics & $\begin{array}{c}0.416 \\
(0.091)^{* * *}\end{array}$ & $\begin{array}{l}0.408 \\
(0.092)^{* * *}\end{array}$ & $\begin{array}{c}0.417 \\
(0.092)^{* * * *}\end{array}$ & $\begin{array}{l}0.401 \\
(0.093)^{* * *}\end{array}$ & $\begin{array}{c}0.299 \\
(0.096)^{* * * *}\end{array}$ \\
\hline Insecurity & & & $\begin{array}{l}-0.836 \\
(0.201)^{* * *}\end{array}$ & $\begin{array}{l}-0.807 \\
(0.201)^{* * *}\end{array}$ & $\begin{array}{l}-0.992 \\
(0.214)^{* * * *}\end{array}$ \\
\hline Akan & & & & $\begin{array}{c}0.288 \\
(0.190)\end{array}$ & $\begin{array}{c}0.270 \\
(0.185)\end{array}$ \\
\hline Krou & & & & $\begin{array}{c}0.544 \\
(0.207)^{* * *}\end{array}$ & $\begin{array}{c}0.588 \\
(0.202)^{* * * *}\end{array}$ \\
\hline Mands & & & & $\begin{array}{c}0.506 \\
(0.241)^{* *}\end{array}$ & $\begin{array}{c}0.401 \\
(0.243)^{*}\end{array}$ \\
\hline Mandn & & & & $\begin{array}{c}0.160 \\
(0.201)\end{array}$ & $\begin{array}{l}-0.041 \\
(0.199)\end{array}$ \\
\hline Ethnic & & & & & $\begin{array}{c}0.518 \\
(0.126)^{* * *}\end{array}$ \\
\hline Religion & & & & & $\begin{array}{l}-0.028 \\
(0.251)\end{array}$ \\
\hline Money & & & & & $\begin{array}{c}0.161 \\
(0.146)\end{array}$ \\
\hline Charisma & & & & & $\begin{array}{l}-0.130 \\
(0.197)\end{array}$ \\
\hline
\end{tabular}


(Table 5 continued).

\begin{tabular}{|c|c|c|c|c|c|}
\hline & $(1)$ & $(2)$ & (3) & (4) & (5) \\
\hline Other & & & & & $\begin{array}{l}-0.507 \\
(0.169)^{* * *}\end{array}$ \\
\hline No opinion & & & & & $\begin{array}{l}-1.346 \\
(0.124)^{* * *}\end{array}$ \\
\hline Constant & $\begin{array}{l}-2.654 \\
(0.240)^{* * *}\end{array}$ & $\begin{array}{l}-6.598 \\
(0.471)^{* * *}\end{array}$ & $\begin{array}{l}-6.683 \\
(0.474)^{* * *}\end{array}$ & $\begin{array}{l}-7.020 \\
(0.505)^{* * *}\end{array}$ & $\begin{array}{l}-6.467 \\
(0.531)^{* * *}\end{array}$ \\
\hline Obs & 3,672 & 3,672 & 3,672 & 3,672 & 3,672 \\
\hline Co predict & $74.48 \%$ & $74.73 \%$ & $75.14 \%$ & $75.14 \%$ & $77.61 \%$ \\
\hline Prob > chi2 & 0.0000 & 0.0000 & 0.0000 & 0.0000 & 0.0000 \\
\hline \multicolumn{6}{|c|}{ Table 5.2 Marginal effects (elasticity) } \\
\hline & $(1)$ & $(2)$ & $(3)$ & (4) & (5) \\
\hline Age & $\begin{array}{c}0.5608 \\
(0.0485)^{* * *}\end{array}$ & $\begin{array}{c}2.439 \\
(0.1932)^{* * *}\end{array}$ & $\begin{array}{c}2.482 \\
(0.1935)^{* * *}\end{array}$ & $\begin{array}{l}2.502 \\
(0.1924)^{* * *}\end{array}$ & $\begin{array}{c}2.399 \\
(0.1981)^{* * *}\end{array}$ \\
\hline $\mathrm{Age}^{2}$ & & $\begin{array}{l}-0.9051 \\
(0.0867)^{* * *}\end{array}$ & $\begin{array}{l}-0.9236 \\
(0.0867)^{* * *}\end{array}$ & $\begin{array}{l}-0.9343 \\
(0.0864)^{* * *}\end{array}$ & $\begin{array}{l}-0.8864 \\
(0.0888)^{* * *}\end{array}$ \\
\hline Sex & $\begin{array}{l}0.0258 \\
(0.0106)^{* * *}\end{array}$ & $\begin{array}{c}0.0286 \\
(0.0107)^{* * *}\end{array}$ & $\begin{array}{l}0.0297 \\
(0.0106)^{* * *}\end{array}$ & $\begin{array}{c}0.0309 \\
(0.0106)^{* * *}\end{array}$ & $\begin{array}{c}0.0329 \\
(0.0106)^{* * *}\end{array}$ \\
\hline Primary & $\begin{array}{c}0.0129 \\
(0.0064)^{* *}\end{array}$ & $\begin{array}{c}0.0120 \\
(0.0065)^{*}\end{array}$ & $\begin{array}{c}0.0115 \\
(0.0065)^{*}\end{array}$ & $\begin{array}{c}0.0100 \\
(0.0065)\end{array}$ & $\begin{array}{c}0.0052 \\
(0.0066)\end{array}$ \\
\hline Secondary & $\begin{array}{c}0.0256 \\
(0.0111)^{* *}\end{array}$ & $\begin{array}{c}0.0185 \\
(0.0111)\end{array}$ & $\begin{array}{c}0.0185 \\
(0.0114)\end{array}$ & $\begin{array}{c}0.0153 \\
(0.0115)\end{array}$ & $\begin{array}{c}0.0084 \\
(0.0116)\end{array}$ \\
\hline University & $\begin{array}{l}0.0696 \\
(0.0116)^{* * *}\end{array}$ & $\begin{array}{c}0.0626 \\
(0.0118)^{* * *}\end{array}$ & $\begin{array}{c}0.0619 \\
(0.0117)^{* * *}\end{array}$ & $\begin{array}{l}0.0596 \\
(0.0117)^{* * *}\end{array}$ & $\begin{array}{c}0.0530 \\
(0.0119)^{* * * *}\end{array}$ \\
\hline Koran & $\begin{array}{l}-0.0019 \\
(0.0025)\end{array}$ & $\begin{array}{l}-0.0026 \\
(0.0025)\end{array}$ & $\begin{array}{l}-0.0029 \\
(0.0025)\end{array}$ & $\begin{array}{l}-0.0032 \\
(0.0025)\end{array}$ & $\begin{array}{l}-0.0042 \\
(0.0025)^{*}\end{array}$ \\
\hline Worker & $\begin{array}{c}0.0418 \\
(0.0116)^{* * *}\end{array}$ & $\begin{array}{c}0.0294 \\
(0.0115)^{* *}\end{array}$ & $\begin{array}{c}0.0301 \\
(0.0115)^{* * *}\end{array}$ & $\begin{array}{c}0.0325 \\
(0.0115)^{* * *}\end{array}$ & $\begin{array}{c}0.0213 \\
(0.0117)^{*}\end{array}$ \\
\hline Student & $\begin{array}{l}-0.0263 \\
(0.0047)^{* * *}\end{array}$ & $\begin{array}{l}-0.0176 \\
(0.0047)^{* * *}\end{array}$ & $\begin{array}{l}-0.0179 \\
(0.0047)^{* * *}\end{array}$ & $\begin{array}{l}-0.0175 \\
(0.0047)^{* * *}\end{array}$ & $\begin{array}{l}-0.0206 \\
(0.0048)^{* * *}\end{array}$ \\
\hline Retiree & $\begin{array}{c}0.0026 \\
(0.0036)\end{array}$ & $\begin{array}{c}0.0075 \\
(0.0036)^{* *}\end{array}$ & $\begin{array}{c}0.0078 \\
(0.0036)^{* *}\end{array}$ & $\begin{array}{c}0.0080 \\
(0.0036)^{* *}\end{array}$ & $\begin{array}{c}0.0062 \\
(0.0034)^{*}\end{array}$ \\
\hline Democracy & $\begin{array}{c}0.1184 \\
(0.0115)^{* * *}\end{array}$ & $\begin{array}{c}0.1201 \\
(0.0117)^{* * *}\end{array}$ & $\begin{array}{c}0.1164 \\
(0.0117)^{* * *}\end{array}$ & $\begin{array}{c}0.1144 \\
(0.0117)^{* * *}\end{array}$ & $\begin{array}{c}0.0957 \\
(0.0119)^{* * *}\end{array}$ \\
\hline State & $\begin{array}{c}0.0733 \\
(0.0120)^{* * *}\end{array}$ & $\begin{array}{c}0.0739 \\
(0.0121)^{* * *}\end{array}$ & $\begin{array}{c}0.0728 \\
(0.0121)^{* * *}\end{array}$ & $\begin{array}{c}0.0687 \\
(0.0122)^{* * *}\end{array}$ & $\begin{array}{l}0.0450 \\
(0.0124)^{* * *}\end{array}$ \\
\hline Politics & $\begin{array}{c}0.0330 \\
(0.0072)^{* * *}\end{array}$ & $\begin{array}{c}0.0320 \\
(0.0072)^{* * *}\end{array}$ & $\begin{array}{c}0.0326 \\
(0.0072)^{* * *}\end{array}$ & $\begin{array}{c}0.0311 \\
(0.0072)^{* * *}\end{array}$ & $\begin{array}{c}0.0223 \\
(0.0072)^{* * *}\end{array}$ \\
\hline Insecurity & & & $\begin{array}{l}-0.0073 \\
(0.0017)^{* * *}\end{array}$ & $\begin{array}{l}-0.0071 \\
(0.0017)^{* * *}\end{array}$ & $\begin{array}{l}-0.0083 \\
(0.0018)^{* * *}\end{array}$ \\
\hline Akan & & & & $\begin{array}{c}0.0342 \\
(0.0226)\end{array}$ & $\begin{array}{c}0.0309 \\
(0.0212)\end{array}$ \\
\hline Krou & & & & $\begin{array}{c}0.0245 \\
(0.0093)^{* * *}\end{array}$ & $\begin{array}{c}0.0255 \\
(0.0088)^{* * *}\end{array}$ \\
\hline Mands & & & & $\begin{array}{c}0.0085 \\
(0.0040)^{* *}\end{array}$ & $\begin{array}{c}0.0065 \\
(0.0039)^{*}\end{array}$ \\
\hline
\end{tabular}


(Table 5 continued).

\begin{tabular}{|c|c|c|c|c|c|}
\hline & (1) & (2) & (3) & (4) & (5) \\
\hline \multirow[t]{2}{*}{ Mandn } & & & & 0.0082 & -0.0020 \\
\hline & & & & (0.0103) & $(0.0098)$ \\
\hline \multirow[t]{2}{*}{ Ethnic } & & & & & 0.0236 \\
\hline & & & & & $(0.0058)^{* * *}$ \\
\hline \multirow[t]{2}{*}{ Religion } & & & & & -0.0002 \\
\hline & & & & & $(0.0018)$ \\
\hline \multirow[t]{2}{*}{ Money } & & & & & 0.0043 \\
\hline & & & & & $(0.0039)$ \\
\hline \multirow[t]{2}{*}{ Charisma } & & & & & -0.0017 \\
\hline & & & & & $(0.0026)$ \\
\hline \multirow[t]{2}{*}{ Other } & & & & & -0.0010 \\
\hline & & & & & $(0.0025)^{* *}$ \\
\hline \multirow[t]{2}{*}{ No opinion } & & & & & -0.0531 \\
\hline & & & & & $(0.0051)^{* * *}$ \\
\hline Obs & 3,672 & 3,672 & 3,672 & 3,672 & 3,672 \\
\hline
\end{tabular}

Notes. Robust standard errors in parentheses. ${ }^{*}$ significant at $10 \%{ }^{* *}$ significant at $5 \% ;{ }^{* * *}$ significant at $1 \%$.

Precisely, insecurity is associated with a decrease of the probability of voting by $0.73 \%$ (column (3) of Table 5.2). This effect of insecurity is in line with Collier and Vicente's (2008) findings that violence is effective in reducing voter turnout. Therefore, fighting against violence during elections can motivate people to participate in elections.

Column (4) presents the results when the variables of ethnic groups are added to the previous list of explanatory variables. All the significant variables of column (3) are still significant at the same levels of significance, except for the primary education variable. In addition, all the coefficients associated with ethnic groups are positive but only two are significant. The probability of voting is significantly higher for Krou and Mandé du sud than for the Gurr group. But, the propensity to vote is the same for the Gurr, Mandé du nord and Akan ethnic group. The significant effect of Krou and Mandé du sud on the probability of voting may be explained by the fact that the main candidates for the 2000 presidential elections were from these two ethnic groups.

Column (5) reports the results when dummy variables related to criteria adhesion to political parties are added to the list of variables in column (4). Note that all the significant coefficients in column (4) are still significant and that the coefficient associated with secondary education turns out to be weakly significant. The coefficient on the dummy variable capturing ethnic adhesion to political parties is positive and significant while those associated with adhesion based on no criteria (no opinion) and on other criteria (other) are negative and significant. Therefore, respondents who report that adhesion to political parties is based on the ethnic group are more likely to vote than those who said that adhesion relies upon the government program. On the contrary, respondents who have no opinion on the adhesion to political parties or advance criteria of adhesion other than ethnic, religion, money and leader's charisma have a lower propensity to vote.

In summary, the variables that robustly and significantly affect the voting probability are age, sex, university, worker, student, democracy, state, politics, insecurity, Krou, mands and the variables related to criteria of the adhesion to political parties such as ethnic group, other criteria and no criterion. Age has an inverted U-shaped effect on the propensity to vote while all the other variables except insecurity, student, other and no opinion are 
positively associated with the voting probability.

\section{Results for the Vote Choice}

Table 6 presents a tabulation of the main motives for the candidate's choice by voters. This evidence allows us to determine the proportion of people who choose their candidate according to government program, ethnic group, religion, political party or other criteria (experience in politics, wealth, honesty, nationalism, good behavior, peace lover, being a civilian, intelligent...). The proportions are $13.50 \%, 2.31 \%, 0.41 \%, 6.34 \%$ and 77.44\% respectively. Therefore, the majority of people choose their candidate according to individual characteristics of the candidate. This result may be explained by the fact people trust less politicians in corrupted countries such as Côte d'Ivoire (Laporta et al., 1997).

Table 6

Frequency of the Motives for Candidate Choice

\begin{tabular}{lccc}
\hline Motives & Frequency & Frequency in percent & Cumulative frequency \\
\hline Government program & 526 & 13.50 & 13.50 \\
Ethnic & 90 & 2.31 & 15.81 \\
Religion & 16 & 0.41 & 16.22 \\
Political party & 247 & 6.34 & 22.56 \\
Other & 3,017 & 77.44 & 100 \\
Total & 3,896 & 100 & \\
\hline
\end{tabular}

Given the low percentages of ethnic group, religion and political party, we include ethnic group and religion in the alternative "other criteria" and merge "government program" and "political party" into an alternative called "program and party". The alternative obtained by gathering ethnic group, religion and other criteria is named "individual characteristics of the candidate". Therefore, the proportions are $19.50 \%$ for "program and party" and $80.50 \%$ for "individual characteristics of the candidate".

Next, we examine the determinants of the candidate's choice. As already noted, we use all the explanatory variables of the decision to participate in elections except for the dummy variables indicating the possession of the Ivorian identity card. The dependent variable is a dummy variable which takes the value 1 when the candidate is chosen according to individual characteristics and 0 otherwise. As in the previous section, we use a Logit model to estimate the probability of choosing candidate according to individual characteristics. The results are reported in Table 7. Column (1) reports the results when we include only the standard determinants of voting. Only five of the twelve variables are statistically significant. Age is negatively and significantly associated with the probability of choosing the candidate according to his individual characteristics. This result suggests that young voters are less likely to choose candidates according to individual characteristics. On the contrary, the coefficients associated with the dummies representing Koran, secondary and university education levels are positive and significant. Therefore, having such education levels increases the probability of voting according to individual characteristics of the candidate. While the effect of the Koran education is quite normal, the positive effect of the secondary and university education is counterintuitive. Such an effect may be explained by the fact that the 2000 presidential election was a contest between a civilian candidate and a military. In such a context, educated people are more likely to vote for a civilian candidate who is more likely to promote democracy than a military regime. Similarly, the dummy state is positively and significantly associated with the probability of voting according to candidates' individual characteristics. This result implies that respondents who answered that 
the state of Côte d'Ivoire protects the population without discrimination are more likely to vote according to individual characteristics.

Column (2) presents the results when the dummy variable of insecurity is included in the model. All the significant variables of column (1) are still significant at the same levels of significance. Moreover, insecurity is negatively and significantly associated with the probability of choosing the candidate on the basis of his individual characteristics. Therefore people who complained about insecurity during elections are more likely to vote according to the government program.

Table 7

Results for Vote Choice

\begin{tabular}{|c|c|c|c|c|}
\hline \multicolumn{5}{|c|}{ Table 7.1 Estimated coefficients } \\
\hline & (1) & (2) & (3) & (4) \\
\hline Age & $\begin{array}{l}-0.013 \\
(0.004)^{* * *}\end{array}$ & $\begin{array}{l}-0.013 \\
(0.004)^{* * *}\end{array}$ & $\begin{array}{l}-0.013 \\
(0.004)^{* * *}\end{array}$ & $\begin{array}{l}-0.012 \\
(0.004)^{* * *}\end{array}$ \\
\hline Sex & $\begin{array}{l}-0.025 \\
(0.092)\end{array}$ & $\begin{array}{l}-0.020 \\
(0.092)\end{array}$ & $\begin{array}{l}-0.015 \\
(0.092)\end{array}$ & $\begin{array}{l}-0.034 \\
(0.095)\end{array}$ \\
\hline Primary & $\begin{array}{l}-0.102 \\
(0.143)\end{array}$ & $\begin{array}{l}-0.110 \\
(0.144)\end{array}$ & $\begin{array}{l}-0.118 \\
(0.144)\end{array}$ & $\begin{array}{l}-0.126 \\
(0.147)\end{array}$ \\
\hline Secondary & $\begin{array}{c}0.461 \\
(0.140)^{* * *}\end{array}$ & $\begin{array}{l}0.463 \\
(0.141)^{* * * *}\end{array}$ & $\begin{array}{c}0.451 \\
(0.142)^{* * * *}\end{array}$ & $\begin{array}{c}0.354 \\
(0.144)^{* *}\end{array}$ \\
\hline University & $\begin{array}{c}0.576 \\
(0.152)^{* * *}\end{array}$ & $\begin{array}{c}0.571 \\
(0.152)^{* * *}\end{array}$ & $\begin{array}{c}0.554 \\
(0.153)^{* * *}\end{array}$ & $\begin{array}{l}0.547 \\
(0.157)^{* * * *}\end{array}$ \\
\hline Koran & $\begin{array}{c}0.452 \\
(0.218)^{* *}\end{array}$ & $\begin{array}{l}0.442 \\
(0.217)^{* *}\end{array}$ & $\begin{array}{l}0.455 \\
(0.219)^{* *}\end{array}$ & $\begin{array}{c}0.410 \\
(0.221)^{*}\end{array}$ \\
\hline Worker & $\begin{array}{l}-0.069 \\
(0.100)\end{array}$ & $\begin{array}{l}-0.065 \\
(0.100)\end{array}$ & $\begin{array}{l}-0.061 \\
(0.100)\end{array}$ & $\begin{array}{l}-0.028 \\
(0.102)\end{array}$ \\
\hline Student & $\begin{array}{c}0.093 \\
(0.170)\end{array}$ & $\begin{array}{c}0.081 \\
(0.170)\end{array}$ & $\begin{array}{c}0.077 \\
(0.170)\end{array}$ & $\begin{array}{c}0.014 \\
(0.176)\end{array}$ \\
\hline Retiree & $\begin{array}{l}-0.055 \\
(0.221)\end{array}$ & $\begin{array}{l}-0.050 \\
(0.222)\end{array}$ & $\begin{array}{l}-0.053 \\
(0.223)\end{array}$ & $\begin{array}{c}0.011 \\
(0.230)\end{array}$ \\
\hline Democracy & $\begin{array}{l}-0.111 \\
(0.095)\end{array}$ & $\begin{array}{l}-0.128 \\
(0.095)\end{array}$ & $\begin{array}{l}-0.134 \\
(0.096)\end{array}$ & $\begin{array}{l}-0.163 \\
(0.097)^{*}\end{array}$ \\
\hline State & $\begin{array}{c}0.276 \\
(0.094)^{* * * *}\end{array}$ & $\begin{array}{l}0.270 \\
(0.094)^{* * * *}\end{array}$ & $\begin{array}{c}0.261 \\
(0.094)^{* * * *}\end{array}$ & $\begin{array}{c}0.288 \\
(0.097)^{* * * *}\end{array}$ \\
\hline Politics & $\begin{array}{l}-0.141 \\
(0.092)\end{array}$ & $\begin{array}{l}-0.137 \\
(0.092)\end{array}$ & $\begin{array}{l}-0.135 \\
(0.092)\end{array}$ & $\begin{array}{l}-0.018 \\
(0.095)\end{array}$ \\
\hline Insecurity & & $\begin{array}{l}-0.479 \\
(0.202)^{* *}\end{array}$ & $\begin{array}{l}-0.453 \\
(0.203)^{* * *}\end{array}$ & $\begin{array}{l}-0.375 \\
(0.208)^{*}\end{array}$ \\
\hline Akan & & & $\begin{array}{l}-0.077 \\
(0.210)\end{array}$ & $\begin{array}{l}-0.005 \\
(0.213)\end{array}$ \\
\hline Krou & & & $\begin{array}{l}-0.163 \\
(0.224)\end{array}$ & $\begin{array}{l}-0.074 \\
(0.227)\end{array}$ \\
\hline Mands & & & $\begin{array}{l}-0.163 \\
(0.257)\end{array}$ & $\begin{array}{l}-0.098 \\
(0.258)\end{array}$ \\
\hline Mandn & & & $\begin{array}{l}-0.223 \\
(0.218)\end{array}$ & $\begin{array}{l}-0.122 \\
(0.221)\end{array}$ \\
\hline Ethnic & & & & $\begin{array}{l}-1.065 \\
(0.113)^{* * *}\end{array}$ \\
\hline
\end{tabular}


(Table 7 continued).

\begin{tabular}{|c|c|c|c|c|}
\hline & $(1)$ & $(2)$ & (3) & (4) \\
\hline \multirow[t]{2}{*}{ Religion } & & & & 0.172 \\
\hline & & & & $(0.304)$ \\
\hline \multirow[t]{2}{*}{ Money } & & & & -0.907 \\
\hline & & & & $(0.138)^{* * *}$ \\
\hline \multirow[t]{2}{*}{ Charisma } & & & & -1.498 \\
\hline & & & & $(0.165)^{* * *}$ \\
\hline \multirow[t]{2}{*}{ Other } & & & & -0.816 \\
\hline & & & & $(0.165)^{* * *}$ \\
\hline \multirow[t]{2}{*}{ No opinion } & & & & -0.100 \\
\hline & & & & $(0.205)$ \\
\hline \multirow{2}{*}{ Constant } & 1.567 & 1.594 & 1.737 & 2.152 \\
\hline & $(0.210)^{* * *}$ & $(0.211)^{* * *}$ & $(0.282)^{* * *}$ & $(0.292)^{* * *}$ \\
\hline Obs & 3,672 & 3,672 & 3,672 & 3,672 \\
\hline Co predict & $80.47 \%$ & $80.47 \%$ & $80.47 \%$ & $80.34 \%$ \\
\hline \multirow[t]{3}{*}{ Prob > chi2 } & 0.0000 & 0.0000 & 0.0000 & 0.0000 \\
\hline & & rginal effects & ice (elasticity) & \\
\hline & $(1)$ & $(2)$ & (3) & (4) \\
\hline \multirow[t]{2}{*}{ Age } & -0.0878 & -0.0868 & -0.0872 & -0.0745 \\
\hline & $(0.0280)^{* * *}$ & $(0.0281)^{* * * *}$ & $(0.0281)^{* * *}$ & $(0.0266)^{* * *}$ \\
\hline \multirow[t]{2}{*}{ Sex } & -0.0023 & -0.0019 & -0.0014 & -0.0029 \\
\hline & $(0.0086)$ & $(0.0086)$ & $(0.0086)$ & $(0.0082)$ \\
\hline \multirow[t]{2}{*}{ Primary } & -0.0034 & -0.0037 & -0.0039 & -0.0039 \\
\hline & $(0.0048)$ & $(0.0048)$ & $(0.0048)$ & $(0.0046)$ \\
\hline \multirow[t]{2}{*}{ Secondary } & 0.0292 & 0.0292 & 0.0284 & 0.0209 \\
\hline & $(0.0089)^{* * *}$ & $(0.0089)^{* * *}$ & $(0.0089)^{* * *}$ & $(0.0084)^{* *}$ \\
\hline \multirow[t]{2}{*}{ University } & 0.0332 & 0.0328 & 0.0318 & 0.0293 \\
\hline & $(0.0087)^{* * *}$ & $(0.0087)^{* * * *}$ & $(0.0088)^{* * *}$ & $(0.0084)^{* * *}$ \\
\hline \multirow[t]{2}{*}{ Koran } & 0.0043 & 0.0042 & 0.0044 & 0.0037 \\
\hline & $(0.0021)^{* *}$ & $(0.0021)^{* *}$ & $(0.0021)^{* *}$ & $(0.002)^{*}$ \\
\hline \multirow[t]{2}{*}{ Worker } & -0.0066 & -0.0061 & -0.0058 & -0.0024 \\
\hline & $(0.0094)$ & $(0.0094)$ & $(0.0094)$ & (0.009) \\
\hline \multirow[t]{2}{*}{ Student } & 0.0023 & 0.002 & 0.0019 & 0.0003 \\
\hline & $(0.0043)$ & $(0.0043)$ & $(0.0043)$ & $(0.0041)$ \\
\hline \multirow[t]{2}{*}{ Retiree } & -0.0005 & -0.0004 & -0.0005 & -0.00009 \\
\hline & $(0.0020)$ & $(0.0020)$ & $(0.0020)$ & (0.0019) \\
\hline \multirow[t]{2}{*}{ Democracy } & -0.0114 & -0.0130 & -0.0137 & -0.0155 \\
\hline & $(0.0097)$ & $(0.0097)$ & $(0.0098)$ & $(0.0092)^{*}$ \\
\hline \multirow[t]{2}{*}{ State } & 0.0299 & 0.0291 & 0.0281 & 0.0289 \\
\hline & $(0.0101)^{* * *}$ & $(0.0101)^{* * * *}$ & $(0.0101)^{* * *}$ & $(0.0097)^{* * *}$ \\
\hline \multirow[t]{2}{*}{ Politics } & -0.0085 & -0.0082 & -0.0081 & -0.0010 \\
\hline & $(0.0055)$ & $(0.0055)$ & $(0.0055)$ & $(0.0053)$ \\
\hline \multirow[t]{2}{*}{ Insecurity } & & -0.0032 & -0.0031 & -0.0024 \\
\hline & & $(0.0014)^{* *}$ & $(0.0014)^{* *}$ & $(0.0014)^{*}$ \\
\hline \multirow[t]{2}{*}{ Akan } & & & -0.0070 & -0.0004 \\
\hline & & & $(0.0193)$ & (0.0183) \\
\hline
\end{tabular}


(Table 7 continued).

\begin{tabular}{|c|c|c|c|c|}
\hline \multicolumn{5}{|c|}{ Table 7.2 Marginal effects for vote choice (elasticity) } \\
\hline & $(1)$ & $(2)$ & (3) & (4) \\
\hline \multirow[t]{2}{*}{ Krou } & & & -0.0057 & -0.0024 \\
\hline & & & $(0.0078)$ & $(0.0074)$ \\
\hline \multirow[t]{2}{*}{ Mands } & & & -0.0021 & -0.0012 \\
\hline & & & $(0.0033)$ & $(0.0031)$ \\
\hline \multirow[t]{2}{*}{ Mandn } & & & -0.0089 & -0.0045 \\
\hline & & & $(0.0087)$ & $(0.0082)$ \\
\hline \multirow[t]{2}{*}{ Ethnic } & & & & -0.0365 \\
\hline & & & & $(0.0037)^{* * *}$ \\
\hline \multirow[t]{2}{*}{ Religion } & & & & 0.0009 \\
\hline & & & & $(0.0017)$ \\
\hline \multirow[t]{2}{*}{ Money } & & & & -0.0183 \\
\hline & & & & $(0.0027)^{* * *}$ \\
\hline \multirow[t]{2}{*}{ Charisma } & & & & -0.0152 \\
\hline & & & & $(0.165)^{* * *}$ \\
\hline \multirow[t]{2}{*}{ Other } & & & & -0.0093 \\
\hline & & & & $(0.0019)^{* * *}$ \\
\hline \multirow[t]{2}{*}{ No opinion } & & & & -0.0012 \\
\hline & & & & $(0.0024)$ \\
\hline Obs & 3,672 & 3,672 & 3,672 & 3,672 \\
\hline
\end{tabular}

Notes. Robust standard errors in parentheses; ${ }^{*}$ significant at $10 \% ;{ }^{* *}$ significant at $5 \%$; ${ }^{* * *}$ significant at $1 \%$.

Column (3) presents the results when the variables of ethnic groups are added to the previous list of explanatory variables. All the significant variables of column (1) are still significant at the same levels of significance. However, the coefficients associated with ethnic group variables are not statistically significant. These results suggest that the ethnic origin does not matter for the choice of the candidate.

Column (4) reports the results when the dummy variables related to criteria of the adhesion to political parties are added to the list of variables in column (5). Note that all the significant coefficients in column (3) are still significant (with a decreased level of significance for Koran and insecurity variables) and that the coefficient associated with the dummy variable democracy turns out to be weakly significant. In addition, the variables related to adhesion to political party such as ethnic, money, charisma and other criteria are both negatively and significantly connected to voting according to individual characteristics of the candidate. These results imply that relative to people who respond that the adhesion to political parties is based on the government program, respondents who answer that the adhesion is according to ethnic group, money, the leader charisma or other criteria are less likely to choose their candidate on the basis of their characteristics. In terms of marginal effects, a year increase in age decreases the probability of voting according to individual characteristics by $0.074 \%$ while having a secondary, university or Koran education levels increases this probability by $2.09 \%, 2.93 \%$ and $0.37 \%$, respectively. Satisfaction with democracy decreases the probability of voting according to individual characteristics of the candidate by $1.55 \%$ whereas satisfaction with the state increases this probability by $2.89 \%$. Insecurity is associated with a decrease in the probability of choosing the candidate on the basis of his characteristics by $0.24 \%$. Similarly, report adhere to political parties according to ethnic group, money, the leader charisma or other criteria reduces this probability by $3.65 \%, 1.83 \%, 1.52 \%$ and $0.93 \%$ respectively. 


\section{Conclusion}

This paper examined the determinants of the decision to vote and the vote choice in presidential elections in Côte d'Ivoire using a dataset financed by the European Commission in 2005. The decision to vote and the vote choice are estimated using Logit models. We have found that the probability of voting varies across ethnic groups and significantly increases with education levels, interest in politics, satisfaction with democracy and satisfaction with government but decreases with insecurity during elections. Moreover, we have found that there is an inverted U-shaped relationship between age and the probability of voting. This probability is high for men compared to women and for workers and retirees compared to the unemployed while it is low for students. Respondents who have no opinion on adhesion criteria or report that adhesion to political parties is based on the ethnic group, religion, money or leader's charisma are more likely to vote than those who said that adhesion relies upon the government program.

Concerning the vote choice, we have found that $19.50 \%$ of the voters choose candidates according to the government program and the political party, while $80.50 \%$ vote according to the individual characteristics of the candidate. Concerning the "program and party" criterion, the probability of choosing the candidate on the basis of his individual characteristics decreases with age, insecurity, satisfaction with democracy and adhesion based on ethnic group, money, leader's charisma or other criteria. On the other hand, this probability is high for people with a secondary, university or Koran education level and for people satisfied with government.

Together these results suggest two sets of policy responses. The first set concerns the mobilization of voters and the second set is about actions for getting elected. To mobilize people to vote, one must, for example, pay attention to young and old voters and women and strengthen security during elections. The incumbent government should also promote democracy and protect citizens without any discrimination. To win elections, on top of having a government program, political parties should select candidate according to criteria such as experience in politics, wealth, honesty, nationalism, loving peace.

\section{References}

Brady, H. E., Verba, S., \& Lehman, K. S. (1995). Beyond SES: A resource model of political participation. American Political Science Review, 89(6), 271-294.

Collier, P., \& Rohner. (2008). Democracy, development, and conflict. Journal of the European Economic Association, 6(2-3), 531-540. Collier, P., \& Vicente, P. C. (2008). Votes and violence: Evidence from a field experiment in Nigeria. HiCN Working paper No.50.

Dalton, R. J. (2007). The good citizen: How a younger generation is reshaping American politics. Washington: Congressional Quarterly Press.

Dalton, R. J., \& Martin, P. W. (2001). Parties without partisans. Oxford: Oxford University Press.

Fournier, P. et al. (2007). The determinants of youth political participation: Conventional versus non-conventional. Paper presented at ECPR Conference in Pisa, Italy September 6-8, 2007.

Grondlund, K., \& Setala, M. (2007). Political trust, satisfaction and voter turnout. Comparative European Politics, 5(4), $400-422$.

Heterington, J. M. (1999). The effect of political trust on the presidential vote, 1968-1996. The American Political Science Review, 93(2), 311-326.

Laporta, R., Florencio, L. S., Schleifer, A., \& Vishny, R. W. (1997). Trust in large organizations. American Economic Review Papers and Proceedings, 87, 333-338.

Mangu, B. M. A. (2008). Elections, Conflits et Crises Politiques en Afrique. Paper presented at African Network of Constitutional Law Conference in Dakar, Senegal, August 28-30, 2008.

Milbrath, L. W., \& Goel, M. L. (1977). Political participation. Chicago: Rand McNally.

Rocco, L., \& Ballo, Z. (2008). Provoking a civil war. Public Choice, 134(3-4), 346-366.

Verba, S., \& Norman, H. N. (1972). Participation in America: Political democracy and social equality. New York: Harper \& Row. Winkler, J. D., Judd, C. M., \& Kelman, H. C. (1981). Determinants of political participation in a Canadian and a United States City. Political Psychology, 3(3-4), 140-161. 